\section{Sinn over kropp - den kloke nevrolog}

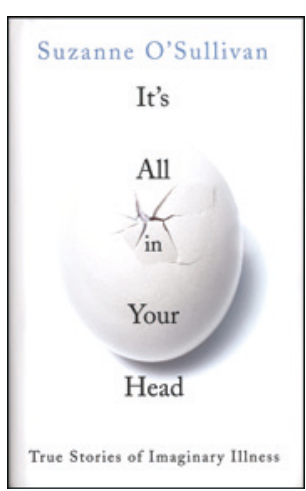

Forfatteren er nevrolog ved National Hospital of Neurology and Neurosurgery i London og bygger sin bok på klinisk erfaring gjennom mer enn 20 år. Hun skildrer pasienter med lammelser, blindhet, krampeanfall, smerter og kronisk tretthet, der man ikke finner noen organisk årsak. Ifølge forfatteren har opp mot en tredel av pasientene $i$ en vanlig nevrologisk avdeling uforklarlige symptomer.

Disse tilstandene har vært kjent langt tilbake og finnes i alle kulturer og har seilt under forskjellige diagnoser, fra hysteri og psykosomatisk lidelse til somatoforme forstyrrelser. Gjennom de siste par tiårene har fibromyalgi, kronisk tretthetssyndrom og myalgisk encefalopati (ME) vært $\mathrm{i}$ vinden.

Da nevrologien vokste frem, ble spinal irritasjon en viktig årsak. Etter 1850 kom teorien om nasal irritasjon. Kauterisering av nesens mucosa ble vanlig. Til og med Sigmund Freud (1856-1939) søkte hyppig slik behandling.

Jean Martin Charcot (1825-1893) var en av de mest innflytelsesrike legene i det 19. århundre. Han brukte tiår på å forstå hysterien og var den første som studerte den vitenskapelig. Charcot, som opprinnelig var patolog, undersøkte sine pasienter over tid, også post mortem, og kunne slik skille ut en rekke nevrologiske sykdommer. Det underlige er at Charcot, på tross av at han ikke fant noen somatisk årsak, holdt fast på at hysteri var en organisk sykdom. Det var Pierre Janet (1859-1947), fransk filosof, psykolog og lege, som med sin teori om det ubevisste brakte hysterien tilbake til vårt sinn etter Charcots død. Freud «stjal» ideer fra både Charcot og Janet og ekspanderte sine teorier.

Etter en grundig somatisk-nevrologisk undersøkelse må legen fortelle slike pasienter det de helst ikke vil høre - at deres plager er «all in their mind». $\AA$ få pasienten til å akseptere at hennes - det er ofte en kvinne - symptomer er av psykisk art og at psykiatrisk behandling kanskje er det beste, er en kunst. Men som forfatteren sier, å gi pasienten en somatisk, altså en feil diagnose, kan føre til livslange plager uten bedring. Både her i landet og andre steder finnes det mange pasienter som går på antiepileptisk medikasjon til ingen nytte.

Forfatteren skriver interessant. Enkelt og klart dveler hun instruktivt ved en del sykehistorier og diskuterer disse, som fortsatt $i$ en del tilfeller er en teoretisk gåte, samtidig som hun i historiske sidesprang gir et bilde av hysterien gjennom de siste par hundre år.

Dette er en bok som kan anbefales alle leger, ikke minst sakkyndige $\mathrm{i}$ forsikringssaker.

\section{Forvitneleg om bakteriofagar}

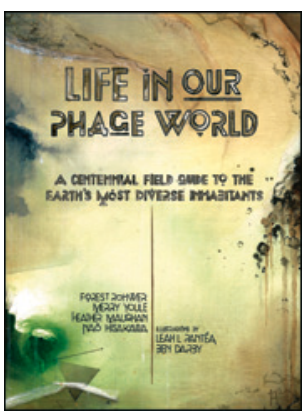

Forest Rohwer, Merry Youle,

Heather Maughan

Life in our phage world

A centennial field guide to the earth's most diverse inhabitants. 404 s, tab, ill. San Diego, CA: Wholon, 2014. USD 83

ISBN 978-0-9904943-0-0

Alle som har arbeidt ved eit mikrobiologisk laboratorium har sett at det av og til ser ut som om ei mus har vore borte og teke ein liten bit av kanten på bakteriekoloniane, eller at tett vekst på ei resistensskål ser ut som om det har gått møll i den. Fenomenet vart observert av Frederick W. Twort (1877-1950) i 1915, og, uavhengig av han, av Félix d'Hérelle (1873-1949) i 1917. Dei meinte begge at det kunne vere eit virus som var årsaken, og d'Hérelle fann på nemninga bakteriofag.

Inspirert av «hundreårsjubileet» har Forest Rohwer og medarbeidarar oppsummert mykje av det vi i dag veit om bakteriofagar, i Life in our phage world, og det er ikkje lite. Og samstundes er det så uendeleg mykje vi ikkje veit om dei.

Dette er inga lærebok. Det er ei forvitneleg oversikt over bakteriofagar: kva dei er, kva dei gjer, kvar dei lever, korleis dei lever. Visste du at det i ein milliliter sjøvatn er like mange fagpartiklar som det er innbyggjarar i Rio de Janeiro? At det er $10^{31}$ fagpartiklar på jorda (ti bakteriofagar for kvar bakterie), og dersom ein legg dei side ved side, rekk dei 42 millionar lysår ut i rommet?

Forfattarane tek for seg mangfaldet hjå desse småkrypa: korleis dei samspelar med bakteriar, Archaea og Protista. Dei finst overalt, «der som ingen skulle tru at nokon kunne bu». Dei har utvikla mange fascinerande strategiar for å feste seg til og smyge seg inn i vertsorganismen. Dei kan drepe han, eller dei kan slå seg til ro der inne, tilføre nye eigenskapar, og dra med seg genmateriale frå verten til neste offer, og på den måten fungere som ein gedigen genbank.

30 ulike bakteriofagar er gjennomgått nokså detaljert: fysiske karakteristika, genkart, korleis dei infiserar offera sine, og replikering. Dei ulike forfattarane, åtte i talet, skriv relativt lettlese og, ikkje minst, humørfylt. Det er ikkje til å unngå at det vert litt repetisjon her og der, men det er til å leve med. Boka er gjennomillustrert med teikningar av fagpartiklane (gode teikningar, ikkje ullen elektronmikroskopi) og meir kunstnarleg framstilling av infeksjon og replikering. Det siste er nok mindre vellukka - ein kunne ynskje seg at det var litt meir distinkt og litt mindre kunst.

Boka er eit funn for alle med interesse for biologi, ikkje berre for mikrobiologar. Den kostar 60 britiske pund hjå Amazon, men kan lastast ned gratis frå http://coralandphage.org/. Men med $323 \mathrm{Mb}$ lyt du vere tolmodig. Dessutan: ei bok i handa er betre enn $323 \mathrm{Mb}$ på skjermen!

\section{Eirik Holten}

Pensjonert lege, Hagan 